\title{
PENGARUH PENAMBAHAN SERBUK ARANG CANGKANG KEMIRI - BARIUM KARBONAT TERHADAP PERMUKAAN PAHAT BUBUT DENGAN MENGGUNAKAN METODE PACK CARBURIZING
}

\author{
Khairul Ummurani \\ Syahrul Fathi \\ Iqbal Tanjung* \\ Program Studi Teknik Mesin. Universitas Muhammadiyah Sumatera Utara
}

\begin{abstract}
This research is focused on surface treatment to improve the physical and mechanical repair of low carbon steel by carburizing method. One of the solid media commonly used is candlenut shell charcoal. Candlenut shells have a carbon presentation value of $76.31 \% .4$ test specimens were prepared in this study. The test specimen is a carbide insert lathe tool. The carburizing process in this study uses candlenut shell charcoal with the addition of active ingredients so that the process of adding carbon to the media takes place in a gas state. The active ingredient chosen is barium carbonate $(\mathrm{BaCO} 3)$, with a percentage of $40 \%$. The test specimens are mixed with the two materials into a steel cylinder tube which is afterward heated into a heating furnace with a temperature of $800{ }^{\circ} \mathrm{C}-950{ }^{\circ} \mathrm{C}$ for a long duration of 8 hours and cooled slowly. The micro test results showed that there was a structural change on the surface of the test specimen. Furthermore, the hardness test results show that the hardness value of the lathe tool has increased after the carburizing process is carried out. The test specimen without carburizing process has a Vickers hardness value of 1.619. Hereinafter, specimens that have been carburized have an average Vickers hardness value of 1.73. The highest hardness value occurs at point 5 of the test on specimen 2. Based on the test results, it was found the surface hardness value of the specimen was successfully increased by the Pack Carburizing method.
\end{abstract}

Keywords:

Carburizing; Candlenut Shell Charcoal; carbide tools; Micro Structure; Hardness Vickers.

\begin{abstract}
Abstrak
Penelitian ini difokuskan pada perlakuan permukaan untuk memperbaiki fisis dan mekanis baja karbon rendah dengan metode carburiszing. Salah satu media padat yang umum digunakan ialah arang cangkang kemiri. Cangkang kemiri memiliki nilai presentasi karbon sebesar 76,31\%. 4 spesimen uji disiapkan dalam penelitian ini. Spesimen uji merupakan pahat bubut berjenis karbida sisipan. Proses carburizing pada penelitian ini menggunakan arang cangkang kemiri dengan penambahan bahan aktif sehingga proses penambahan karbon terhadap media berlangsung dalam keadaan gas. Bahan aktif yang dipilih ialah barium karbonat $(\mathrm{BaCO} 3)$ dengan presentase $40 \%$. Spesimen uji dicampurkan dengan kedua bahan ke dalam tabung silinder baja yang selanjutnya dipanaskan ke dalam tungku pemanas dengan suhu $800{ }^{\circ} \mathrm{C}-950{ }^{\circ} \mathrm{C}$ dengan lama durasi selama 8 jam dan didinginkan dengan udara lingkungan secara perlahan. Hasil pengujian uji mikro menunjukkan terjadi perubahan struktur pada permukaan spesimen uji. Selanjutnya hasil pengujian kekerasan menunjukkan nilai kekerasan pada pahat bubut mengalami peningkatan setelah dilakukan proses carburizing. Spesimen uji tanpa proses carburizing memiliki nilai kekerasan Vickers sebesar 1,619. Selanjutnya spesimen yang telah dilakukan proses carburizing memiliki nilai rata-rata kekerasan Vickers sebesar 1,731. Nilai kekerasan tertinggi terjadi pada titik 5 pengujian pada spesimen 2. Berdasarkan hasil pengujian didapatkan nilai kekerasan permukaan spesimen uji berhasil ditingkatkan dengan metode Pack Carburizing.
\end{abstract}

Kata Kunci:

Carburizing; Arang Cangkang Kemiri; Mata Pahat Karbida; Struktur Mikro; Hardness Vickers.

DOI: $10.38038 /$ vocatech.v2i2.61

Received: 25 March 2021 ; Accepted: 20 April 2021 ; Published: 26 April 2021

\section{*Corresponding author:}

Iqbal Tanjung, Program Studi Teknik Mesin. Universitas Muhammadiyah Sumatera Utara. Jl. Kapten Muchtar Basri No.3, Medan, Sumatera Utara 20238.

Email: iqbaltanjung@umsu.ac.id

Citation in APA Style: Ummurani, K., Fathi, S., \& Tanjung, I. (2021). Pengaruh Penambahan Serbuk Arang Cangkang Kemiri - Barium Karbonat terhadap Permukaan Pahat Bubut dengan Menggunakan Metode Pack Carburizing. VOCATECH: Vocational Education and Technology Journal Vol. 2, 2 (2021), $120-128$. 


\section{PENDAHULUAN}

Perlakuan permukaan untuk memperbaiki fisis dan mekanis pada baja karbon rendah sering dilakukan, baik pada industri kecil maupun besar. Salah satu metode perlakuan pengerasan permukaan terhadap baja karbon rendah tersebut adalah proses Carburizing. Proses ini dilakukan dengan menambahkan karbon pada baja yang diikuti dengan proses pengerasan permukaan. Proses karburising padat merupakan proses yang paling sederhana dibandingkan proses karvurising lainnya, hal ini dikarenakan proses ini tidak membutuhkan perlengkapan khusus.

Proses carburizing menggunakan media padat umumnya dilakukan pada temperatur $842^{\circ} \mathrm{C}-953{ }^{\circ} \mathrm{C}$ selama waktu tertentu sehingga atom-atom karbon dari karburiser akan berdifusi ke permukaan baja karbon rendah. Proses difusi atom-atom karbon ini terjadi secara interstisi, dimana atom-atom yang berukuran lebih kecil akan menyisip pada ronggarongga kosong di antara atom-atom logam yang memiliki ukuran yang lebih besar (Budinski \& Budinski, 1999; Callister Jr \& Rethwisch, 2020; (Darmo et al., 2018).

Salah satu media padat yang umum digunakan adalah arang cangkang kemiri. Cangkang kemiri memiliki nilai presentasi karbon sebesar $76,31 \%$. Media ini menjadi salah satu bahan yang cocok sebagai media pack karburising, mengingat ketersedian yang cukup banyak dan memiliki presentasi kabon yang cukup tinggi. Untuk menjadikan arang cangkang kemiri sebagai sumber karbon, cangkang kemiri terlebih dahulu diubah menjadi bentuk butiran. Bentuk butiran akan membantu proses perubahan karbon padat menjadi gas melalui pemanasan.

Karakteristik mata pahat merupakan faktor yang sangat penting dalam proses pemesinan. Secara garis besar mata pahat harus memiliki tingkat keras permukaan, ulet, tahan panas dan tahan terhadap gesekan yang baik. Hal ini guna menunjang performa proses pemesinan yang baik. Upaya memperbaiki sifat kekerasan pada baja telah dilakukan beberapa dekade belakangan ini. Salah satu proses yang dilakukan adalah dengan menambahkan kadar karbon pada logam tersebut memalui proses pack carburizing (Kuswanto, 2010; (Mulyanto et al., 2013; Prayoga, n.d.; Tryanto, n.d.).

Sehingga menambahkan kadar karbon pada mata pahat melalui proses pack carburizing menjadi satu topik yang sangat menarik. Objektif dari penelitian ini adalah untuk mengamati pengaruh penambahan kadar karbon arang cangkang kemiri melalui proses pack carburuzing pada pahat bubut sisipan karbida terhadap perubahan permukaan struktur mikro dan nilai kekerasan permukaan yang diharapkan dapat menambah umur pakai terhadap mata pahat tersebut.

\section{STUDI PUSTAKA}

\section{A. Mata Pahat Karbida}

Salah satu mata pahat yang umum digunakan dalam proses pemesinan adalah mata pahat berjenis karbida. Mata pahat karbida merupakan pahat potong yang memiliki nilai kekerasan berkisar antara $\mathrm{Rc}=90-93$. Pahat ini juga mampu menerima temperatur kerja yang cukup tinggi berkisar antara $1000^{\circ} \mathrm{C}$ dan dapat bekerja dengan kecepatan potong 2 sampai 5 kali lebih tinggi dari jenis pahat HSS berkisar $120-230 \mathrm{~m} / \mathrm{menit}$.

Mata pahat karbida dibuat dengan proses sintering. Umumnya bahan ini merupakan paduan dari beberapa material yang dicetak menggunakan pelumas (lilin) dengan metode cetak tekan. Mata pahat karbida diklasifikasikan menjadi tiga jenis yaitu Karbida Tungsten, Karbida Tungsten Paduan dan Karbida Lapis. Pada studi ini jenis mata pahat yang digunakan adalah Karbida Tungsten contoh mata pahat karbida sisipan ditunjukkan pada Gambar 1.

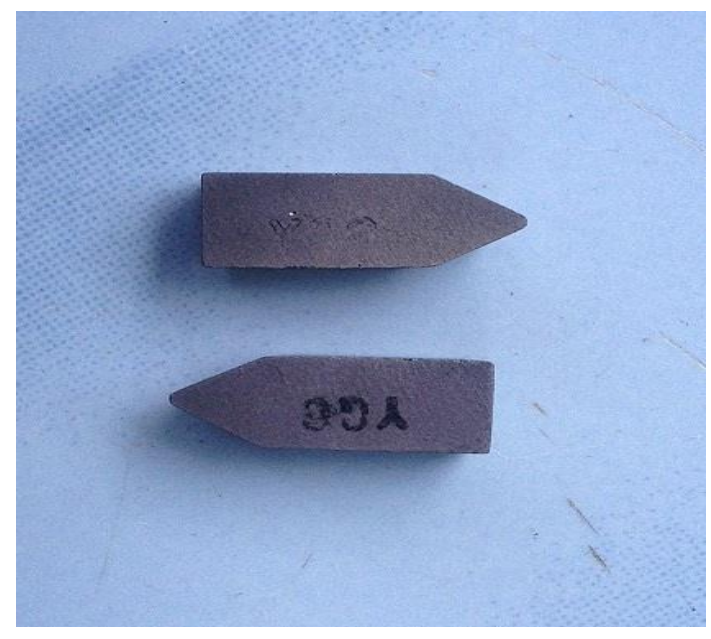

Gambar 1. Mata Pahat Karbida Sisipan

\section{B. Pengerasan Permukaan (Surface Hardening)}

Pengerasan permukaan merupakan suatu proses dalam rekayasa material yang bertujuan untuk merubah karakteristik permukaan material. Secara 
harfiah proses ini dilakukan dengan dua metode yaitu dengan menambahkan unsur kimia lain sehingga terjadinya perubahan komposisi pada material yang akan direkayasa atau dengan merubah struktur kristal dari material tersebut.

Pengerasan permukaan pada material dapat dilakukan melalui beberapa metode diantaranya adalah Karburasi, Karbonitriding dan Cyaniding. Metode yang paling sering digunakan adalah Karburasi (carburizing), metode ini dilakukan dengan memanaskan baja pada suhu $842-953^{\circ} \mathrm{C}$ dalam lingkungan yang mengandung karbon, dengan memanaskan material sampai temperatur kritis mengakibatkan material mengalami afinitast. Sehinga karbon diabsorpsi ke dalam logam membentuk larutan padat dan lapisan luar memiliki karbon kadar tinggi. Bila dibiarkan lebih lama, karbon akan mempunyai kesempatan untuk berdifusi ke bagian lebih dalam. Tebal lapisan tersebut tergantung terhadap waktu dan temperatur pada saat perlakuan panas (Hassan, 2015; Sabri, 2010; Supriyono, 2018).

\section{Carburizing}

Carburizing adalah proses penambahan unsur karbon yang berdifusi pada permukaan logam untuk meningkatkan sifat fisik dan mekanik. Proses karburasi biasanya dilakukan pada baja karbon rendah yang memiliki kelenturan tinggi. Pengerasan permukaan logam dengan menggunakan metode karburasi adalah cara pengerasan tertua dan ekonomis Karena proses pengerasan ini hanya mengubah komposisi kimia dari baja karbon.

Penambahan karbon pada baja dilakukan menggunakan tiga cara yaitu: pack carburizing, proses liquid carburizing dan proses gas carburizing. Proses pack carburizing didefinisikan sebagai proses pelapisan permukaan baja dengan karbon padat di dalam kotak tertutup rapat, diikuti dengan pemanasan diatas temperatur kritis. Karbon padat yang biasa digunakan umumnya berupa arang kayu, kokas, arang tempurung kelapa, arang cangkang kemiri, arang cangkang sawit, arang kulit kenari walaupun tidak menutup kemungkinan penggunaan dari sumber karbon lainnya.

Proses pack carburizing dilakukan dengan karbon monoksida yang berasal dari senyawa padat terurai pada permukaan logam, hal ini mengakibatkan terbentuknya karbon baru dan karbon dioksida. Pembentukan karbon monoksida ditingkatkan oleh energizer atau katalis, seperti barium karbonat (BaCO3), kalsium karbonat
(CaCO3), kalium karbonat (K2CO3), dan natrium karbonat (Na2CO3).

Pada metode pack carburizing atau karburisasi padat, komponen yang akan dikarburisasi ditempatkan dalam kotak yang berisi media penambah unsur karbon atau media karburasi, kemudian dipanaskan pada suhu austenisasi (842$953^{\circ} \mathrm{C}$ ). Akibat pemanasan ini, media karburasi akan teroksidasi menghasilkan gas $\mathrm{CO} 2$ dan $\mathrm{CO}$.

Gas CO2 ini sebagian akan bereaksi kembali dengan media karbon membentuk $\mathrm{CO}$ dan sebagian lagi akan menguap. Ketersedian oksigen yang cukup di dalam kotak dapat membantu kelancaran reaksi pengkarbonan. Media karburasi yang berbentuk serbuk akan memunculkan ronggarongga di dalam kotak. Semakin besar ukuran serbuk maka semakin besar rongganya, namun akan makin sedikit kontak antara media karburasi dengan permukaan komponen. Ukuran serbuk yang besar juga akan mengurangi efektifitas proses karburisasi padat. Di sisi lain, semakin kecil ukuran serbuk semakin kecil rongganya sehingga mengurangi jumlah oksigen dalam kotak. Mekanisme proses pack carburizing ditunjukkan pada Gambar 2.

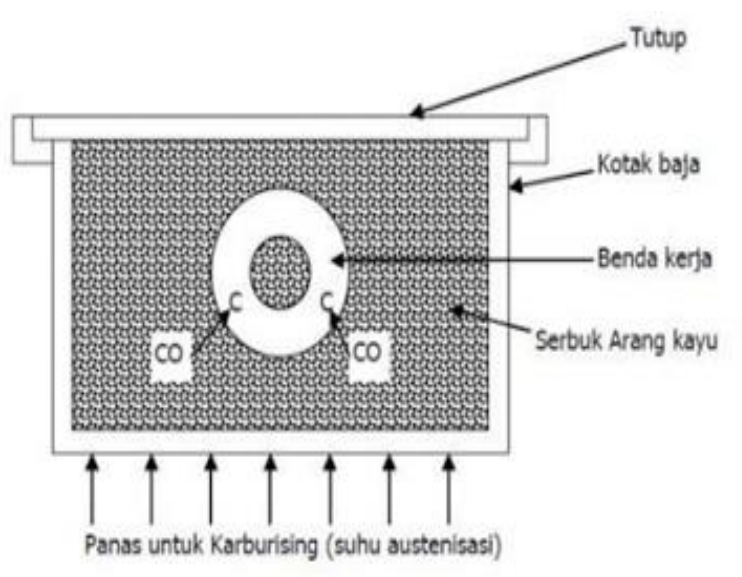

Gambar 2. Mekanisme Pack Carburizing

\section{Difusi Atom}

Ketika temperatur meningkat atom-atom di dalam cairan padat mengalami vibrasi yang lebih energetic, maka sebagian kecil fraksi dari atomatom tersebut akan mengalami perubahan posisi dalam kisi. Tidak hanya tergantung pada temperatur, tetapi juga tergantung pada seberapa eratnya atom-atom terikat pada posisinya. Energi yang diperlukan oleh sebuah atom untuk mengubah posisi disebut energi aktivasi. 
Atom karbon mempunyai ukuran cukup kecil dengan $\mathrm{r}=0,07 \mathrm{~nm}$. Ukuran tersebut dapat menempati posisi interstisial diantara sejumlah atom, jika atom karbon mempunyai cukup energi. Energi atom karbon untuk melakukan difusi tersebut membutuhkan sekitar $34000 \mathrm{kal} / \mathrm{mol}$ ( $\mathrm{Hu}$ et al., 2019; Jia-min, 2000; Li \& Yang, 2004; Negara et al., 2015; Parrish, 1999; Perrusquia et al., 2020) (Radomysel'skii et al., 1965). Mekanisme Pergerakan atom terhadap energi aktifitas ditunjukkan pada Gambar 3.

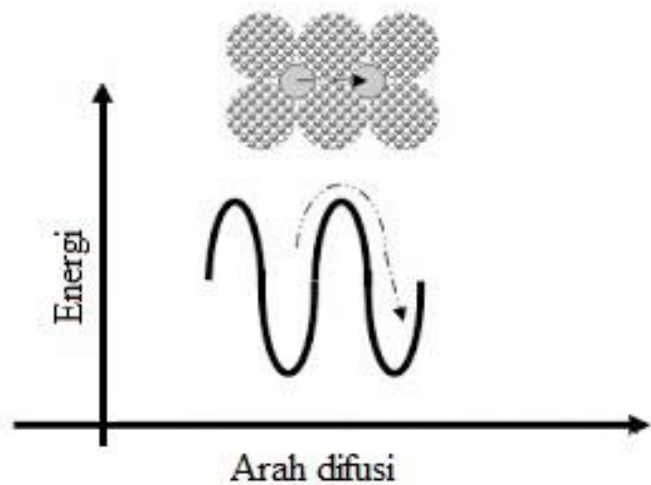

Gambar 3. Pergerakan Atom dengan Energi Aktifitas

\section{E. Arang Cangkang Kemiri}

Kemiri merupakan tumbuhan yang sering dijumpai di negara tropis seperti Indonesia. Berdasarkan data pusat statistik pada tahun 2014 produksi tumbuhan kemiri sebesar 107,3 ribu ton (BPS, 2014). Ketersediaan yang cukup banyak membuat tumbuhan ini diolah menjadi beragam produk dan diproduksi masal, akan tetapi tidak semua bagian dari tumbuhan ini dapat diolah menjadi sebuah produk, cangkang dari tumbuhan kemiri merupakan salah satu limbah yang cukup banyak dan dibiarkan begitu saja. Upaya untuk mengatasi hal ini diperlukannya suatu terobosan untuk mengurangi tingkat limbah cangkang kemiri segingga memiliki nilai ekonomis tinggi. Pengolahan cangkang kemiri menjadi arang aktif telah dilakukan secara luas pada beberapa tahun terakhir. Bentuk limbah cangkang kemiri ditunjukkan pada Gambar 4.

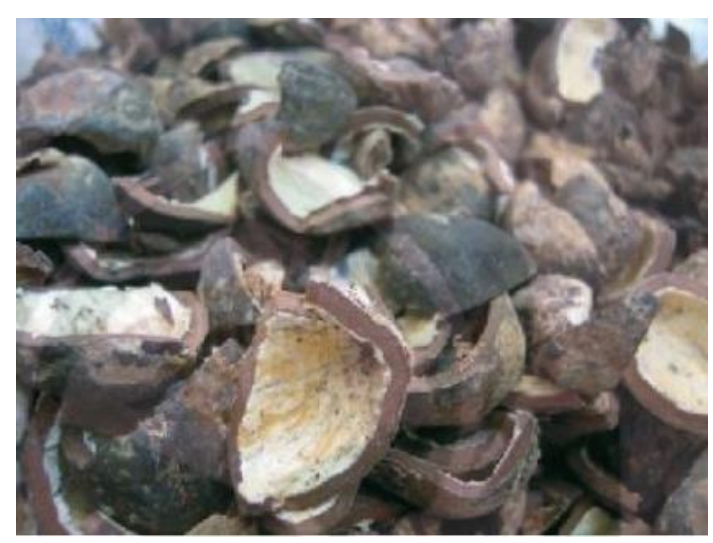

Gambar 4. Cangkang Kemiri

Karakter cangkang yang keras mengakibatkan limbah ini menjadi limbah organik yang sulit terurai secara alamiah. Namun karakter yang keras ini menjadikan cangkang kemiri dapat dimanfaatkan sebagai bahan baku dalam pembuatan arang aktif. Arang aktif merupakan karbon yang memiliki pori-pori terbuka sehingga memiliki nilai penyerapan yang lebih tinggi dibandingkan dengan arang biasa. Arang aktif merupakan bahan karbon amorf dengan susunan atom karbon bebas dengan permukaan dalam sehingga memiliki nilai penyerapan yang cukup tinggi (Surtamtomo et al., n.d.; Dailami et al., 2020).

Ketersediaan yang cukup banyak dan memiliki nilai presentase karbon tinggi mengakibatkan arang cangkang kemiri merupakan pilihan yang cukup popular digunakan untuk proses karburasi. Arang cangkang kemiri memiliki nilai presentase karbon sebesar $76,31 \%$. Presentase kadar karbon pada beberapa media ditunjukkan pada Tabel 1 .

Tabel 1. Nilai Kadar Karbon pada Beberapa Media

\begin{tabular}{llc}
\hline No & \multicolumn{1}{c}{ Media Padat } & $\begin{array}{c}\text { Presentase } \\
\text { kadar } \\
\text { karbon \% }\end{array}$ \\
\hline 1 & Bubuk karbon aktif & 95 \\
2 & Arang cangkang kemiri & 76,31 \\
3 & Arang cangkang kenari & 77 \\
4 & Arang cangkang sawit & 70 \\
5 & Arang kokas & 80 \\
\hline
\end{tabular}

\section{F. Pengujian Vickers}

Pengujian Vickers merupakan salah satu metode untuk mengetahui nilai kekerasan pada suatu material. Pengujian Vickers pertama kali dikembangkan di Inggris tahun 1925. Pada umumnya pengujian Vickers dilakukan 
menggunakan indentor intan berbentuk piramid dengan besar sudut terhadap permukaan sebesar $136^{\circ}$. Nilai ini dipilih berdasarkan hasil perbandingan antara diameter bola penumbuk pada uji kekerasan brinell (Dieter, 1987).

Nilai kekerasan Vickers didefinisikan terhadap beban yang dibagi luas permukaan. Luas ini dihitung berdasarkan panjang mikroskopik diagonal dari jejak yang dapat ditentukan dengan persamaan dibawah ini.

$$
V H N=\frac{2 P \sin (\theta / 2)}{d^{2}}=\frac{(1,854) P}{d^{2}}
$$

Dimana P merupakan beban yang digunakan $(\mathrm{kg}), \mathrm{d}$ panjang diagonal rata-rata $(\mathrm{mm})$ dan $\theta$ merupakan sudut permukaan intan terhadap permukaan sebesar $136^{\circ}$. Mekanisme pengujian Vickers pada suatu material ditunjukkan pada Gambar 5.

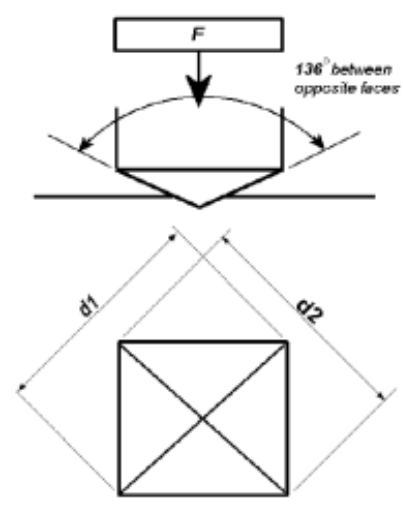

Gambar 5. Mekanisme Pengujian Vickers (N. Dowling, 1993.)

\section{G. Pengujian Struktur Mikro}

Suatu logam mempunyai sifat mekanik yang tidak hanya tergantung pada komposisi kimia suatu paduan, tetapi juga tergantung pada struktur mikronya. Suatu paduan dengan komposisi kimia yang sama dapat memiliki struktur mikro yang berbeda, dan sifat mekaniknya pun akan berbeda. Ini tergantung pada proses pengerjaan dan proses perlakuan panas yang diterima selama proses pengerjaan. Pengamatan struktur mikro umumnya dilakukan dengan menggunakan mikroskop optik. Mekanisme kerja mikroskop optik dapat dilihat pada Gambar 6.

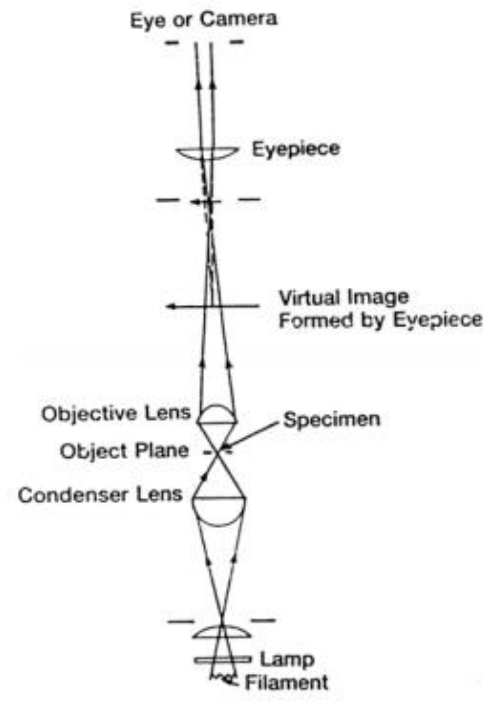

Gambar 6. Mekanisme Kerja Mikroskop Optik

Baja merupakan paduan $\mathrm{Fe}$ dan $\mathrm{C}$ dengan kandungan karbon kurang dari 2,1\%. Besi murni sering disebut ferit (Gambar 2.7(a)). Baja itu sendiri menurut kandungan karbonnya terbagi menjadi yaitu baja hypotektoid dan baja eutectoid hypereutektoid (Gambar, (b), (c), dan (d)). Pada suhu ruang, baja hypotektoid (kandungan karbon kurang dari $0,77 \%$ ) terdiri dari butir-butir kristal ferrit clan perlit. Baja hypereutektoid berupa jaringan sementit dan perlit, sedangkan untuk baja eutektoid terdiri dari perlit eutektoid.
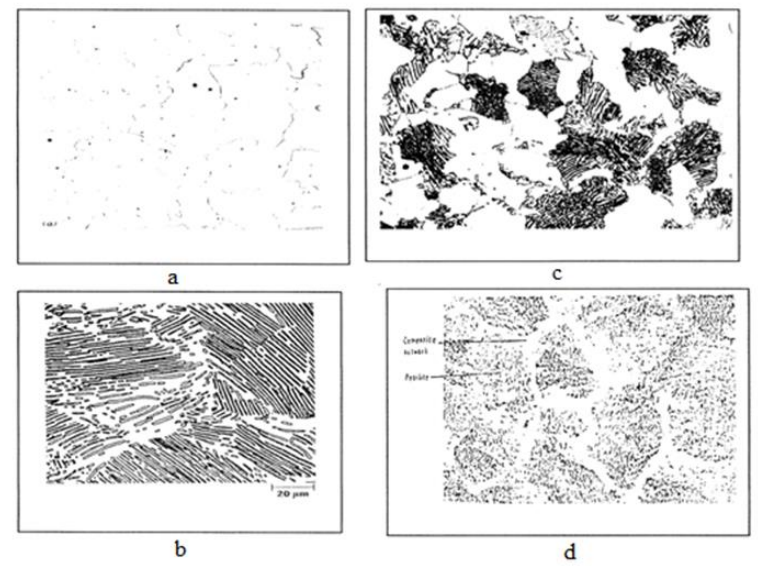

Gambar 7. Struktur mikro baja (a) ferit, $\mathrm{C}=0 \%$ pembesaran $95 \mathrm{X}$, (b) Hipotektoid, $\mathrm{C}=0,38 \%$ pembesaran $635 \mathrm{x}$, (c) Perlit pembesaran 500 X, dan (d) Hipereutektoid C $=1,0 \%$ pembesaran $1000 \mathrm{X}$. 
Dalam suatu proses laku panas, transformasi austenit pada pendinginan memegang peranan penting terhadap sifat baja yang dikenai suatu proses laku panas. Austenit dari baja hypoeutektoid bila didinginkan dengan lambat maka pada temperatur kamar akan berstruktur mikro ferit (proeutektoid) dan struktur yang berlapis-lapis (lamellar) terdiri dari ferrit dan sementit, yang disebut perlit (pearlite). Semakin tinggi kadar karbon dari baja ini makin banyak jumlah perlitnya dibandingkan dengan jumlah ferritnya, clan struktur akan terdiri dari perlit seluruhnya pada baja dengan komposisi eutektoid (baja eutektoid, 0,77 \% C) (Surdia \& Saito, 1992).

Transformasi dari austenit menjadi perlit terjadi karena perpindahan atom-atom secara difusi, karenanya akan memerlukan waktu lama. Dengan pendinginan lambat akan tersedia cukup waktu berlangsungnya difusi sehingga dapat terbentuk perlit yang lamellar. Bila pendinginan agak cepat maka tidak lagi cukup waktu untuk menyelesaikan seluruh transformasi pada temperatur eutektoid kritis. Transformasi akan berlangsung pada temperatur yang lebih rendah, dan pada temperatur yang lebih rendah ini gerakan atom-atom (difusi) menjadi lebih terbatas, sehingga lebar lamel menjadi lebih kecil dan butiran-butiran kristal yang terjadi akan lebih kecil atau halus. Bahkan bila pendinginan berlangsung lebih cepat lagi akan dapat terbentuk struktur mikro yang berbeda dari apa yang terbentuk pada pendinginan lambat yaitu menjadi fasa martensit yang bersifat mekanis sangat keras tetapi getas.

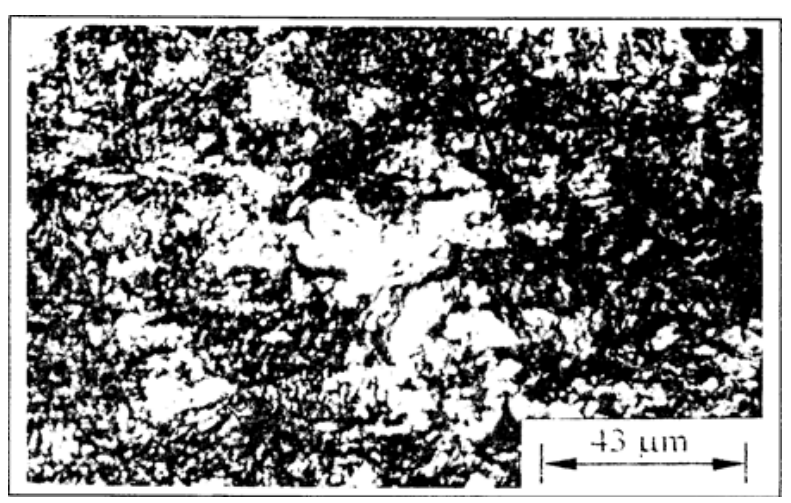

Gambar 8. Struktur Martensit 200X Pembesaran

Dalam diagram $\mathrm{Fe}-\mathrm{Fe} 3 \mathrm{C}$ di atas paduan $\mathrm{Fe}$ dan $\mathrm{C}$ dimana kandungan karbon lebih besar dari 2,1\% sampai dengan 6,57 \%, maka disebut besi cor . Besi cor bermacam-macam jenisnya tergantung dari proses dan sifat mekanisnya

\section{METODE}

Pada penelitian ini 4 spesimen uji disiapkan, dimana 3 spesimen uji yang akan dilakukan proses carburizing dan 1 spesimen tanpa proses carburizing. Spesimen uji merupakan pahat bubut berjenis karbida sisipan. Pemilihan bahan ini mengacu pada beberapa pertimbangan seperti ukuran sampel dan sebagainya. Proses carburizing pada penelitian ini menggunakan arang cangkang kemiri dengan penambahan bahan aktif sehingga proses penambahan karbon terhadap media berlangsung dalam keadaan gas. Bahan aktif yang dipilih adalah barium karbonat $(\mathrm{BaCO} 3)$ dengan presentase $40 \%$.

Spesimen uji dicampurkan dengan kedua bahan kedalam tabung silinder baja yang selanjutnya dipanaskan kedalam tungku pemanas dengan suhu $800{ }^{\circ} \mathrm{C}-950^{\circ} \mathrm{C}$ dengan lama durasi selama 8 jam dan didinginkan menggunakan udara lingkungan secara perlahan. Tabung silinder baja dan dapur pemanas yang digunakan pada penelitian ini ditunjukkan pada gambar 9 .
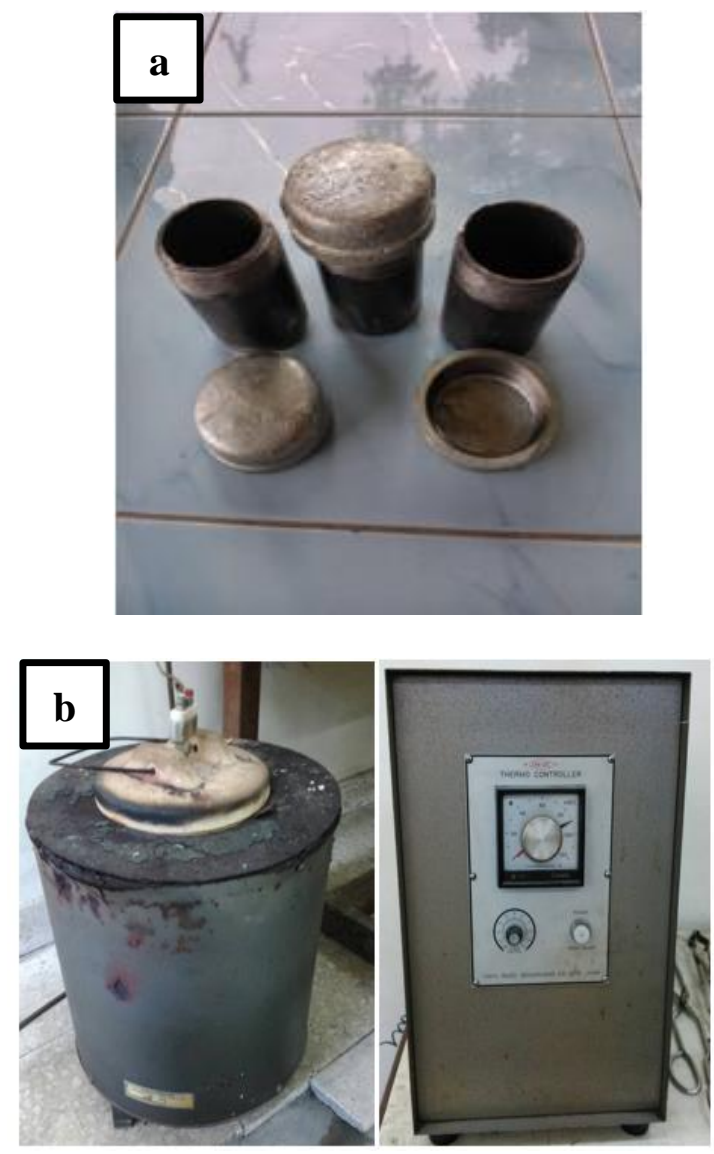

Gambar 9. (a) Media Carburizing, (b) Dapur Pemanas. 
Setelah seluruh proses carburizing selesai selanjutnya spesimen uji diuji nilai kekerasan permukaannya menggunakan alat uji kekerasan (Vicker) dan diamati struktur mikro pada permukaan spesimen menggunakan mikroskop metalografi (E92-17, 2017; Vander Voort, 1999). Pengujian kekerasan permukaan dilakukan pada beberapa titik permukaan spesimen seperti yang ditunjukkan pada gambar 10 .

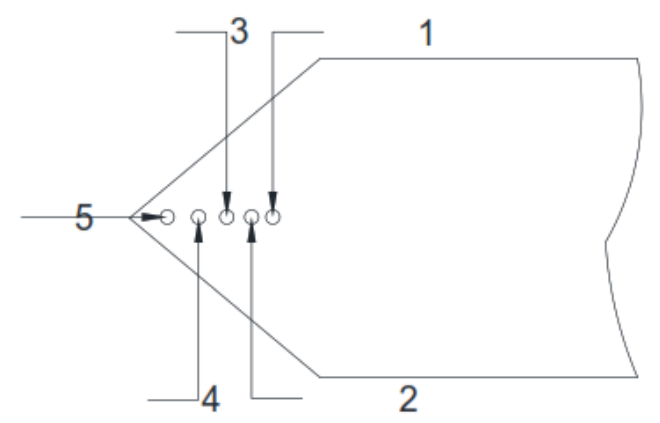

Gambar 10. Titik Pengujian Kekerasan

\section{HASIL DAN PEMBAHASAN}

Setelah didinginkan secara perlahan menggunakan udara lingkungan, spesimen uji mengalami perubahan warna permukaan. Hal ini mengindikasikan proses pack carburizing pada umumnya, dimana terjadi oksidasi yang mengakibatkan karbon dipermukaan terbakar dan meninggalkan sisa pembakaran pada permukaan dalam tabung. Hasil spesimen setelah dilakukan proses carburizing ditunujukkan pada gambar 11 .

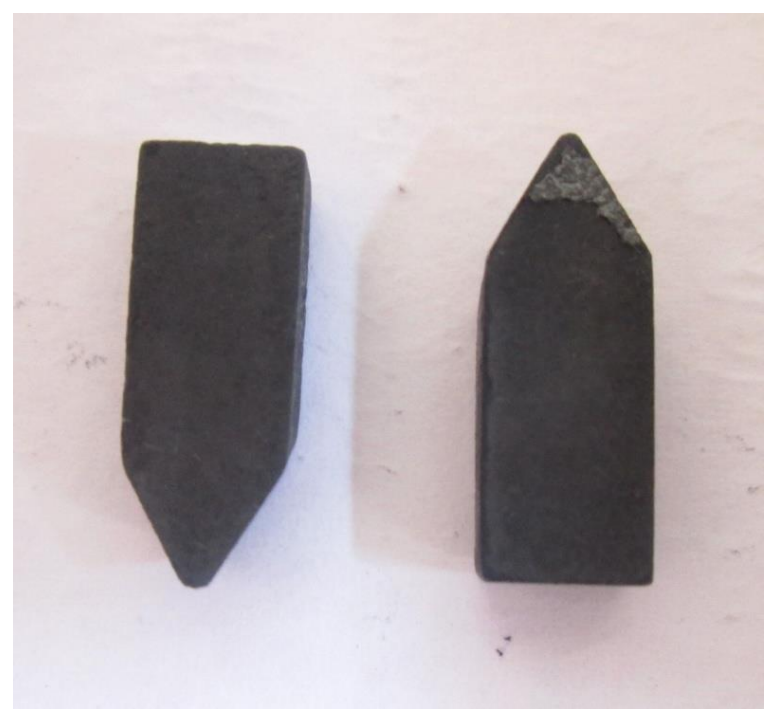

Gambar 11. Spesimen Setelah Proses Carburizing
Selanjutnya hasil pengujian struktur mikro ditunjukkan pada gambar 12. Hasil pengujian menunjukan terjadi perubahan struk pada sisi tepi spesimen uji, ini ditunjukkan titik - titik hitam yang ditunjukkan pada gambar 12b, hal ini menunjukkan bahwa karbon yang berasal dari cangkang kemiri dan balium karbonat telah masuk kedalam permukaan spesimen uji.
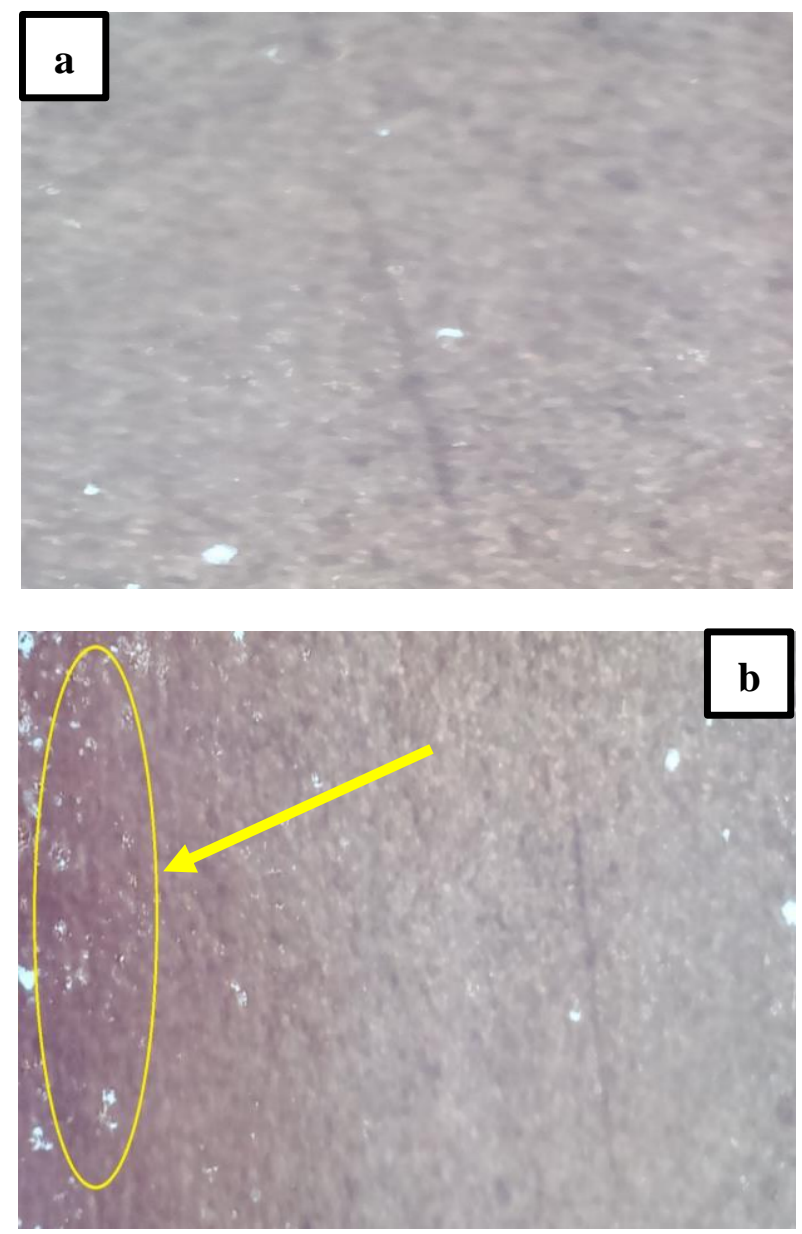

Gambar 12. Struktur Mikro: (a) Sebelum Proses Carburizing (b) Setelah Proses Carburizing

Hasil pengujian menunjukkan kekerasan spesimen tanpa perlakuan pack carburizing memiliki nilai Vickers sebesar 1,619. Selanjutnya hasil pengujian tiga spesimen dengan perlakuan pack carburizing kekerasan menunjukkan pada spesimen 1, 2 dan 3 memiliki nilai kekerasan Vickers sebesar 1,726; 1,770 dan 1,696. Spesimen 2 memiliki nilai rata - rata kekerasan tertinggi diantara semua spesimen. Nilai kekerasan tertinggi terjadi pada titik 5 pengujian pada spesimen 2 . Berdasarkan hasil pengujian didapat nilai kekerasan permukaan spesimen uji berhasil ditingkatkan dengan metode pack carburizing. 
Hasil pengujian kekerasan spesimen ditunjukkan pada gambar 13.

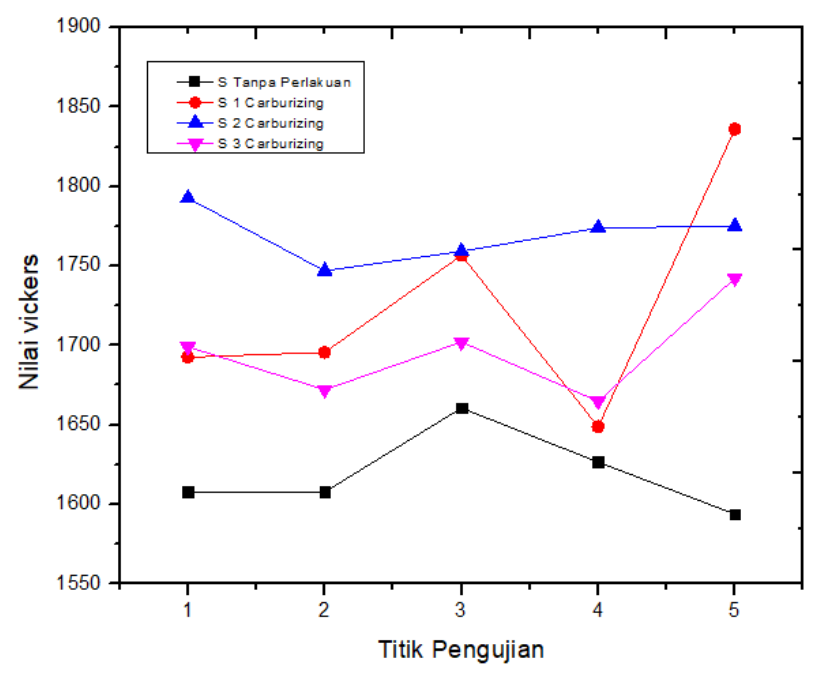

Gambar 13. Nilai Hasil Pengujian Kekerasan

\section{KESIMPULAN}

Berdasarkan hasil yang didapat dapat disimpulkan proses pack carburizing yang dilakukan pada mata pahat sisip karbida berhasil dilakukan, secara keseluruhan metode ini berhasil meningkatkan nilai kekerasan permukaan pada mata pahat sisip karbida dengan meningkatnya nilai kekerasan maka umur penggunaan mata pahat diharapkan semakin meningkat.

\section{REFERENSI}

Budinski, G. K., \& Budinski, K. M. (1999). Chapter 14: Copper and Its Alloys \& Chapter 15: Aluminum and Its Alloys. Stephen Helba (Ed.), Engineering Materials Properties and Selection (Sixth Edit), 521-568.

Callister Jr, W. D., \& Rethwisch, D. G. (2020). Fundamentals of Materials Science and Engineering: An Integrated Approach. John Wiley \& Sons.

Dailami, D., Pribadyo, P., \& Hanif, H. (2020). Pengaruh Komposisi Dan Kuat Tekan terhadap Tingkat Kerapuhan Briket Arang Biomasa Campur Batubara dengan Tepung Kanji sebagai Perekat.
VOCATECH: Vocational Education and Technology Journal, 2(1), 67-72.

Darmo, S., Soenoko, R., Siswanto, E., \& Widodo, T. D. (2018). Study on Mechanical Properties of Pack Carburizing SS400 Steel with Energizer Pomacea Canalikulata Lamarck Shell Powder. International Journal of Mechanical Engineering and Technology (IJMET)-Scope Database Indexed, 9(5), $14-23$.

ASTM E92-17, A. (2017). Standard Test Methods for Vickers Hardness and Knoop Hardness of Metallic Materials. West Conshohocken (PA): ASTM International. Hassan, K. S. (2015). Comparative of Wear Resistance of Low Carbon Steel Pack Carburizing Using Different Media. International Journal of Engineering \& Technology, 4(1), 71.

Hu, K., Wang, G., Li, X., \& Qu, S. (2019). Microstructure and Formation Mechanism in A Surface Carburized Tungsten Heavy Alloy. Journal of Alloys and Compounds, 787, 560-569.

Jia-min, J. I. N. (2000). Re-Exploring on Catalyzing Mechanism of Carbonate in Pack Carburizing. Heat Treatment of Metals, 10.

Kuswanto, B. (2010). Pengaruh Perbedaan Ukuran Butir Arang Tempurung KelapaBarium Karbonat terhadap Peningkatan Kekerasan Permukaan Material Baja ST 37 dengan Proses Pack Carburizing. Diponegoro University.

Li, C. S., \& Yang, Y. S. (2004). A Glass Based Coating for Enhancing Anti-Coking and Anti-Carburizing Abilities of HeatResistant Steel HP. Surface and Coatings Technology, 185(1), 68-73.

Mulyanto, A. E., Pribadi, R. J., \& Solechan, S. (2013). Analisa Penggunaan Tempurung Kelapa untuk Meningkatkan Kekerasan Bahan Pisau Timbangan Meja dengan Proses Pack Carburizing. Prosiding SNST Fakultas Teknik, 1(1).

Negara, D. N. K. P., Muku, I., Sugita, I., Astika, I., Mustika, I. W., \& Prasetya, D. G. R. (2015). Hardness Distribution and 
Effective Case Depth of Low Carbon Steel after Pack Carburizing Process Under Different Carburizer. Applied Mechanics and Materials, 776, 201-207.

Parrish, G. (1999). Carburizing: Microstructures and Properties. Asm International.

Perrusquia, N. L., Ruiz, M. A. D., Bustos, E. D. G., Lores Martinez, M., Calderón, G. M. U., \& San Miguel, C. R. T. (2020). Duplex Surface Treatment on Microalloy Steels by Dehydrated Paste Pack Boriding and Pack Carburizing. Materials Letters, 280, 128573.

Prayoga, A. A. (n.d.). Analisis Pengaruh Ukuran Karbon dan Variasi Unsur Katalis pada Proses Pack Carburizing Karbon Rendah terhadap Struktur Mikro, Case Depth, dan Nilai Kekerasan.

Radomysel'skii, I. D., Zhornyak, A. F., Andreeva, N. V, \& Negoda, G. P. (1965). The Pack Carburizing of Dense Parts from Iron Powder. Soviet Powder Metallurgy and Metal Ceramics, 3(3), 204-211.

Sabri, H. A. B. A. (2010). Experimental Study of Pack Carburizing of Carbon Steel. Bachelor of Engineering Universiti Malaysia Pahang.

Supriyono, S. (2018). The Effects of Pack Carburizing Using Charcoal on Properties of Mild Steel. Media Mesin: Majalah Teknik Mesin, 19(1).

Surdia, T., \& Saito, S. (1992). Pengetahuan Bahan Teknik.(edisi kedua). Jakarta: Pradnya Paramita.

Surtamtomo, I. F., Rifai, M., Maniaryadi, D., Setyaningsih, I., \& Haryati, S. (n.d.). Saifuddin. 1997. Teknologi Adsorbsi Karbon Aktif untuk Mengolah Air Limbah Industri. Balitbang Industri. Departemen Perindustrian dan Perdagangan Republik Indonesia. Semarang.

Tryanto, M. W. (n.d.). Pengaruh Variasi Campuran Cairan Pendingin terhadap Keausan Tepi Pahat HSS (High Speed Steel) pada Proses Bubut Roughing ST 42.

Vander Voort, G. F. (1999). Metallography, Principles and Practice. ASM International. 